\title{
Congressional Power to Renew the Preclearance Provisions of the Voting Rights Act After Tennessee v. Lane
}

\author{
RICHARD L. HASEN*
}

This Article considers a single question: Does Congress have the power to renew the Voting Rights Act's preclearance provisions, set to expire in 2007? Beginning with South Carolina v. Katzenbach, the United States Supreme Court has upheld preclearance as a permissible exercise of congressional enforcement power. These cases, however, mostly predate the Supreme Court's New Federalism revolution. As part of that revolution, the Court has greatly restricted the ability of Congress to pass laws regulating the conduct of the states under its enforcement powers granted in Section Five of the Fourteenth Amendment, which the Court has read as coextensive with its enforcement powers under the Fifteenth Amendment. Moreover, in Board of Trustees v. Garrett, the Court made clear that it will search for an adequate evidentiary record to support a congressional determination that states are engaging in unconstitutional conduct to justify congressional regulation of the states. Some of that clarity on the evidentiary question disappeared in the Court's 2003 decision, Nevada v. Hibbs, and even greater uncertainty has been created by the Court's 2004 decision, Tennessee v. Lane.

Part II of this Article surveys the legal landscape through the developments in Garrett facing those who wish to defend renewed preclearance as an appropriate exercise of congressional power under the Fourteenth or Fifteenth Amendments. Part III then turns to the "Bull Connor is Dead" problem: Most of the original racist elected officials are out of power, and those who remain in power (along with any new elected officials who either intend to discriminate on the basis of race or who otherwise would care less about a discriminatory effect in a change in voting practices or procectures on a protected minority group) have for the most part been deterred by preclearance. Thus, there is not much of a record of recent state-driven discrimination that Congress could point to supporting renewal. The question of how much racial discrimination in voting practices there would be today if we suddenly eliminated preclearance is almost too speculative to answer. It is difficult to see how Congress may prove that preclearance remains necessary under the Garrett-evidentiary standard. Part IV then explains how in two recent cases on congressional power, Nevada v. Hibbs and Tennessee v. Lane, the Supreme Court appears to have backed away from the strict evidentiary standard imposed in Garrett. These cases increase the chances that the Court would hold that Congress has the power to reenact Section Five's preclearance provisions, particularly given Justice Scalia's

- Professor of Law and William M. Rains Fellow, Loyola Law School, Los Angeles. Thanks to Peter Bartle for excellent research assistance. I presented an earlier version of this paper at a Columbia University/NYU School of Law conference on the Future of the Voting Rights Act in September 2003. Thanks to participants there and to Bill Araiza, Sam Bagenstos, Ellen Katz, Rick Pildes, and Michael Waterstone for useful comments and suggestions. 
separate opinion in Lane in which he indicated his new position that Congress has broad latitude to pass legislation aimed at combating racial discrimination. In addition, the Supreme Court's recent opinion in Georgia v. Ashcroft, construing the statutory standard for granting preclearance, takes more pressure off constitutional challenges to a renewed preclearance provision. Part $V$ concludes in a more speculative vein with a look at an alternative basis for congressional power to reenact preclearance: the Guarantee Clause.

\section{INTRODUCTION}

In 1965, Congress enacted the Voting Rights Act. ${ }^{1}$ Section Five of the Act requires that "covered jurisdictions" obtain preclearance from the federal government before making any changes in voting practices or procedures. ${ }^{2}$ Section Five's aim was to prevent state and local governments with a history of discrimination against racial minorities from changing their voting rules without first proving that such changes would have neither a discriminatory purpose nor effect.

Never before (or since) has a state or local jurisdiction needed permission from the federal government to put its own laws into effect. Covered jurisdictions protested that the preclearance rules exceeded congressional power and violated principles of federalism. In the 1966 case, South Carolina v. Katzenbach, ${ }^{3}$ the Supreme Court by an 8-1 vote disagreed. The Court held that the preclearance provision was a permissible exercise of Congress's power to enforce the Fifteenth Amendment's prohibition on racial discrimination in voting. ${ }^{4}$ Congress renewed the preclearance provisions for another twenty-five years in 1982 and the Court again upheld Congress's power to do so..$^{5}$ The current version of Section Five expires in 2007, and Congress may decide to renew it again, perhaps even making it permanent. ${ }^{6}$

This Article considers a single question: Does Congress have the power to renew the Voting Rights Act's preclearance provisions again? Despite South Carolina v. Katzenbach, the answer to that question has become muddled in confusion over the contours of a new set of rules — part of the Supreme Court's "New Federalism" revolution" - regarding the proper scope of congressional enforcement powers granted in Section Five of the Fourteenth Amendment,

142 U.S.C. $\S \S 1973-1973 p$ (2004).

${ }^{2} I d$. at $\S 1973 \mathrm{c}$.

3383 U.S. 301 (1966).

${ }^{4}$ Id. at 337.

${ }^{5}$ Lopez v. Monterey County, 525 U.S. 266, 287 (1999).

${ }^{6}$ See Sheryl Gay Stolberg, Senate Votes to Require Safety Locks on Guns, N.Y. TIMES, Feb. 27, 2004, at A18 (Senate majority leader proposes amendment to other legislation that would make the preclearance provisions of the Act permanent.).

${ }^{7}$ See generally MARK V. TUSHNET, THE NEW CONSTITUTIONAL ORDER 38-55 (2003). 
which the Court has read as coextensive with its enforcement powers under the Fifteenth Amendment. ${ }^{8}$

Beginning with City of Boerne v. Flores, the Court has limited Congress to passing "remedial" statutes. ${ }^{9}$ It has rejected congressional attempts to expand the scope of constitutional rights through legislation beyond that which is "congruen[t] and proportional[]" to remedy intentional unconstitutional discrimination by the states. ${ }^{10}$ In Board of Trustees $v$. Garrett, the Court indicated that it will search for an adequate evidentiary record to support a congressional determination that states are engaging in sufficient intentionally unconstitutional conduct so as to justify congressional regulation. ${ }^{11}$

Following Boerne and Garrett, the road to preclearance renewal could be a rocky one. In 1965 and even in 1982, when Congress reenacted Section Five's preclearance through 2007, Congress could point to significant acts of intentional racial discrimination by covered states to support preclearance provisions. Today, Congress would be hard-pressed to find widespread evidence of such discrimination. I refer to this issue as the "Bull Connor is Dead" problem.

Preclearance has now been in place for almost forty years. Most of the original racist elected officials are out of power, and those who remain in power (along with any new elected officials who either intend to discriminate on the basis of race or who otherwise would care less about a discriminatory effect in a change in voting practices or procedures on a protected minority group) have for the most part been deterred by preclearance. ${ }^{12}$ Thus, there is not much of a record of recent state-driven discrimination that Congress could point to support renewal. The question of how much racial discrimination in voting practices there would be today if we suddenly eliminated preclearance is almost too speculative to answer. How may Congress then prove that preclearance remains necessary under the Boerne/Garrett standard?

Some commentators have looked to Department of Justice's [DOJ] preclearance statistics to find sufficient evidence of a potential for constitutional violations to support preclearance renewal. ${ }^{13} \mathrm{~A}$ closer look at the DOJ's preclearance statistics, however, offers little support for those who wish to build an evidentiary record to support renewal. Other commentators have looked to private acts of discrimination to support renewal. The argument, though creative, probably cannot bear the weight that commentators have put on it given Garrett's focus on proof of state-driven discrimination.

\footnotetext{
${ }^{8}$ Bd. of Trs. v. Garrett, 531 U.S. 356, 373 n.8 (2001).

${ }^{9}$ City of Boeme v. Flores, 521 U.S. 507, 519 (1997).

${ }^{10}$ See, e.g., id. at 520.

11 Garrett, 531 U.S. at 368.

${ }^{12}$ See discussion infra Part III.A.

${ }^{13}$ See discussion infra Part III.B.
} 
Nonetheless, all may not be lost for supporters of renewed preclearance. In the two most recent Supreme Court cases on congressional power, Nevada $v$. $H i b b s^{14}$ and Tennessee $v$. Lane, ${ }^{15}$ the Court appears to have backed away from the strict evidentiary standard imposed in Garrett. These cases increase the chances that the Court would hold that Congress has the power to reenact Section Five's preclearance provisions, particularly given Justice Scalia's separate opinion in Lane in which he indicated his new position that Congress has broad latitude to pass legislation aimed at combating racial discrimination. ${ }^{16}$ In addition, the Supreme Court's recent opinion in Georgia v. Ashcroft, ${ }^{17}$ which construed the statutory standard for granting preclearance, takes more pressure off constitutional challenges to a renewed preclearance provision.

But the significance of these cases should not be overstated. The Court has not formally jettisoned Garrett's evidentiary requirement. Similarly, Justice Scalia has insisted that Congress may impose laws that are aimed at eradicating racial discrimination "only upon those particular States in which there has been an identified history of relevant constitutional violations."18 The Court's majorities in these cases are shifting and uncertain. For these reasons, Congress would be well advised to craft the best evidentiary record possible to support a renewed preclearance provision. In addition, Congress should consider other potential bases of power under which it could reenact the provision.

Part II of this Article surveys the legal landscape through the developments in Boerne and Garrett facing those who wish to defend renewed preclearance as an appropriate exercise of congressional power under the Fourteenth or Fifteenth Amendments. Part III then turns to the Bull Connor is Dead problem: What evidence of intentional racial discrimination can Congress point to supporting a renewed preclearance provision under the test set forth in Boerne and the evidentiary standard set forth in Garrett? Part IV then considers how Hibbs, Lane, and Georgia $v$. Ashcroft make the case for Court approval of a renewed preclearance provision more likely, but far from certain.

Part V concludes in a more speculative vein with a look at an alternative basis for congressional power to reenact preclearance: the Guarantee Clause. Article IV of the Constitution provides that the United States shall guarantee to each state a Republican form of government. ${ }^{19}$ It is an open question whether Congress could reenact the preclearance provisions under the Guarantee Clause and, more provocatively, by doing so insulate the provisions from challenge in the courts

14538 U.S. 721 (2003).

15124 S. Ct. 1978 (2004).

${ }^{16}$ Id. at 2012-13 (Scalia, J., dissenting).

17539 U.S. 461 (2003).

18 Lane, 124 S. Ct. at 2012 (Scalia, J., dissenting).

${ }^{19}$ U.S. CONST. art. IV, $\S 4$. 
under the theory that Guarantee Clause cases raise non-justiciable political questions.

\section{CONGRESSIONAL POWER TO ENFORCE THE FOURTEENTH AND FIFTEENTH AMENDMENTS: FROM KATZENBACH TO BOERNE TO GARRETT ${ }^{20}$}

\section{A. The Early Voting Rights Cases}

When Congress passed the Voting Rights Act in 1965, some southern states immediately challenged it as exceeding congressional power. In the first of these cases, South Carolina v. Katzenbach, South Carolina challenged core provisions of the Act, including the preclearance provision. ${ }^{21}$ The Court rejected South Carolina's argument that the challenged provisions "exceed[ed] the powers of Congress and encroach[ed] on an area reserved to the States by the Constitution." 22 It held that Congress had acted appropriately under its powers granted in Section Two of the Fifteenth Amendment. ${ }^{23}$

In so holding, the Court gave considerable deference to congressional determinations about the means necessary to "enforce" the Fifteenth Amendment. The Court noted that:

Congress had found that case-by-case litigation was inadequate to combat widespread and persistent discrimination in voting, because of the inordinate amount of time and energy required to overcome the obstructionist tactics invariably encountered in these lawsuits. After enduring nearly a century of systematic resistance to the Fifteenth Amendment, Congress might well decide to shift the advantage of time and inertia from the perpetrators of the evil to its victims. $^{24}$

Calling the requirement that a covered jurisdiction obtain federal approval before changing its own laws "uncommon," the Court declared that "exceptional conditions can justify legislative measures not otherwise appropriate. Congress knew that some of the [covered states] had resorted to the extraordinary stratagem

${ }^{20}$ A more extensive discussion of the cases covered in this Part appears in RICHARD L. HASEN, THE SUPREME COURT AND ELECTION LAW: JUDGING EQUALITY FROM BAKER V. CARR TO BUSH V. GORE 120-36 (2003).

${ }^{21}$ South Carolina v. Katzenbach, 383 U.S. 301, 307 (1966).

22 Id. at 323.

${ }^{23}$ Id. at 337. Section One of that amendment prevents the United States or any state from denying or abridging the right of citizens of the United States to vote "on account of race, color, or previous condition of servitude." U.S. CONST. amend. XV, § 1. Section Two declares that "Congress shall have the power to enforce this article by appropriate legislation." Id. at $\S 2$.

${ }^{24}$ Katzenbach, 383 U.S. at 328 (footnote omitted). 
of contriving new rules of various kinds for the sole purpose of perpetuating voting discrimination in the face of adverse federal court decrees."25 Justice Black dissented: "It is inconceivable to me that such a radical degradation of state power was intended in any of the provisions of our Constitution or its Amendments.".26

South Carolina v. Katzenbach showed a Court highly deferential to congressional determinations about how to expand political equality rights, and such deference for the most part continued in three other cases in which the Court faced arguments over the scope of congressional power to enact various provisions of the Voting Rights Act. 27

In Katzenbach v. Morgan, the Court placed one limitation on the expansive view of congressional enforcement power under Section Five of the Fourteenth Amendment. In what has come to be known as the "ratchet theory," Justice Brennan wrote for the Court that Section Five "does not grant Congress power to exercise discretion in the other direction and to enact 'statutes so as in effect to dilute equal protection and due process decisions of this Court."28. Congress could therefore interpret for itself the requirements of the Equal Protection Clause, so long as it does not take away Equal Protection guarantees recognized by the Court.

City of Rome v. United States is most notable for then-Justice Rehnquist's dissent. Under the Act's Section Five, preclearance may not be granted unless the DOJ finds that a voting change had neither a discriminatory purpose nor a discriminatory effect. ${ }^{29}$ The City of Rome argued that Congress could not prohibit voting changes with only a discriminatory effect under its powers granted in Section Two of the Fifteenth Amendment because the Fifteenth Amendment, properly interpreted, barred only purposeful discrimination. ${ }^{30}$

Assuming arguendo the Fifteenth Amendment barred only purposeful discrimination, the Court's majority held that Congress had the power under the Fifteenth Amendment to prevent states from putting into effect laws with a discriminatory effect. "Congress could rationally have concluded that, because electoral changes by jurisdictions with a demonstrable history of intentional racial discrimination in voting create the risk of purposeful discrimination, it was proper to prohibit changes that have a discriminatory impact."31

Then-Justice Rehnquist dissented, arguing that Congress could not properly command the DOJ to bar state and local changes with only a discriminatory effect

25 Id. at 334-35 (citations omitted).

${ }^{26}$ Id. at 360 (Black, J., dissenting).

${ }^{27}$ See City of Rome v. United States, 446 U.S. 156, 187 (1980); Oregon v. Mitchell, 400 U.S. 112, 150 (1970); Katzenbach v. Morgan, 384 U.S. 641, 657-58 (1966).

28 Katzenbach, 384 U.S. at 651 n. 10.

2942 U.S.C. $\$ 1973$ c.

30 City of Rome, 446 U.S. at 173.

31 Id. at 177 (footnote omitted). 
under its enforcement powers of the Fourteenth or Fifteenth Amendments. ${ }^{32} \mathrm{He}$ acknowledged that Congress could do more than simply prohibit unconstitutional conduct; it could "act remedially to enforce the judicially established substantive prohibitions of the Amendments." ${ }^{\text {,33 }}$ Thus, Rehnquist argued that Congress could properly impose a nationwide literacy test as a remedial measure, "effectively preventing purposeful discrimination in the application of the literacy tests as well as an appropriate means of remedying prior constitutional violations by state and local governments in the administration of education to minorities." Congress could not do, Justice Rehnquist wrote, was to "determine for itself that... conduct violates the Constitution." 35 Because he believed that the "effects" test was not remedial to prevent purposeful discrimination, he would have held that this element of the Act's preclearance provision exceeded congressional powers.

\section{B. The "New Federalism" Revolution and the New Evidentiary Burden}

Justice Rehnquist's City of Rome dissent sided with states and localities opposing a broad view of federal government power to regulate state and local voting rules. Justice Powell's separate dissent in City of Rome focused even more directly on concerns that the federal government was intruding on state and local power. ${ }^{36}$ But these arguments in City of Rome failed to persuade a majority of justices in 1980.

In the last decade, however, we have witnessed a federalism revolution in the Supreme Court. Among other things, the Court has limited congressional power under the Commerce Clause (previously thought to be virtually limitless) ${ }^{37}$ and, through its Eleventh Amendment jurisprudence, it has increased the scope of the immunity of states from suits for damages or other retrospective relief for violation of federal law. ${ }^{38}$ The details of this fascinating and seismic shift in power from the federal government to the states are well beyond the scope of the analysis here. Instead, I focus on the one aspect of the federalism cases that bears directly on the preclearance question.

The most relevant "New Federalism" case in this regard is the 1997 Boerne case. ${ }^{39}$ Boerne involved the constitutionality of a congressional statute, the

32 Id. at 215 (Rehnquist, J., dissenting).

${ }^{33} \mathrm{Id}$. at 210 (Rehnquist, J., dissenting) (emphasis added).

${ }^{34}$ Id. at 215 (Rehnquist, J., dissenting).

35 City of Rome, 446 U.S. at 211 (Rehnquist, J., dissenting).

${ }^{36}$ Id. at 193-206 (Powell, J., dissenting).

${ }^{37}$ See, e.g., United States v. Lopez, 514 U.S. 549, 567-68 (1995).

38 See, e.g., City of Boerne v. Flores, 521 U.S. 507, 536 (1997).

${ }^{39} \mathrm{Id}$. 
Religious Freedom Restoration Act of 1993 (RFRA). ${ }^{40}$ RFRA was a congressional reaction to the Supreme Court's controversial 1990 decision in Employment Division Department of Human Resources $v$. Smith, a case holding that neutral, generally applicable laws may be applied to religious practices even when not supported by a compelling governmental interest. ${ }^{41}$ Thus, the Smith Court held that it did not violate the constitutional guarantee of the "free exercise" of religion for the State of Oregon to deny unemployment benefits to Native Americans who lost their jobs for using the illegal drug peyote for sacramental purposes. $^{42}$

Congress enacted RFRA to restore the pre-Smith law by preventing government entities from substantially burdening a person's exercise of religion, even through a rule of general applicability, unless the government could demonstrate that the burden was in furtherance of a compelling governmental interest and was the least restrictive means of furthering that governmental interest. In Boerne, the Catholic Archbishop of San Antonio, Texas sought a building permit to enlarge a church in Boerne, Texas. ${ }^{43}$ Local zoning authorities denied the permit, relying upon an ordinance governing historic preservation in a district that, they argued, included the church. ${ }^{44}$ The Archbishop brought suit, challenging the denial under RFRA. ${ }^{45}$ The Supreme Court held that RFRA, as applied to state and local governments, exceeded congressional power under Section Five of the Fourteenth Amendment. ${ }^{46}$

The Court's analysis began by citing the Voting Rights Act precedents described above as standing for the "broad" power of Section Five. But the Court then held that the Section Five power was limited only to enforcing the provisions of the amendment. ${ }^{47}$ In explaining what the Court believed it meant to "enforce" the amendment, the Court drew a line between legislation that is "remedial," which is within Congress's power, and legislation that makes a "substantive change," which exceeds congressional power. "Congress does not enforce a constitutional right by changing what the right is. It is has been given the power 'to enforce,' not the power to determine what constitutes a constitutional violation." 48 The Court further explained that " $[t]$ here must be a congruence and proportionality between the injury to be prevented or remedied and the means

${ }^{40} I d$. at 512.

41 Employment Div. Dept. of Human Res. v. Smith, 494 U.S. 872, 886-87 (1990).

42 Id. at 890.

43 City of Boerne, 521 U.S. at 512.

${ }^{44}$ Id.

45 Id.

46 Id. at 536.

47 Id. at 519.

${ }^{48}$ City of Boerne v. Flores, 521 U.S. 507, 519 (1997). 
adopted to that end. Lacking such a connection, legislation may become substantive in operation and effect." 49

In so holding, the Court rejected the view of congressional power Justice Brennan advanced for the Court in Morgan. ${ }^{50}$ Although the Boerne Court agreed that there was language in Morgan "which could be interpreted as acknowledging a power in Congress to enact legislation that expands the rights contained in $\S 1$ of the Fourteenth Amendment," the Boerne Court rejected the theory on grounds it would allow Congress to alter the Fourteenth Amendment's meaning without going through the "difficult and detailed amendment process contained in Article V" of the Constitution. ${ }^{51}$

The Court applied this new test for Section Five power to RFRA and held that RFRA came up short. ${ }^{52}$ Along the way, the Court explicitly compared RFRA to the Voting Rights Act. The Court first looked at the evidence before Congress supporting the need for both laws. "In contrast to the record which confronted Congress and the Judiciary in the voting rights cases, RFRA's legislative record lacks examples of modern instances of generally applicable laws passed because of religious bigotry." 53

Moreover, the Court held that while the Voting Rights laws approved in prior cases could be seen as remedial,

RFRA is so out of proportion to a supposed remedial or preventive object that it cannot be understood as responsive to, or designed to prevent, unconstitutional behavior... [Its sweeping] coverage ensures its intrusion at every level of government, displacing laws and prohibiting official actions of almost every description and regardless of subject matter. ${ }^{54}$

The Boerne Court further noted with approval that the laws at issue in the Voting Rights Act cases contained termination dates and geographic restrictions of the law, and the law addressed itself to remedy egregious unconstitutional practices in the states. "[L]imitations of this kind tend to ensure Congress' means are proportionate to ends legitimate under $\S 5 ., 55$

Three post-Boerne Supreme Court cases confirm the substantial narrowing of congressional power under Section Five of the Fourteenth Amendment and the need for Congress to provide adequate evidence of unconstitutional conduct by the states. In Florida Prepaid Postsecondary Education Expense Board v.

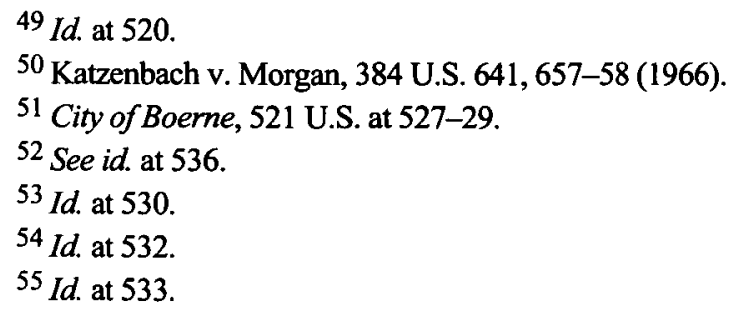


College Savings Bank, the Court held that Congress could not use its Section Five power to subject states to lawsuits for damages for violating a congressional statute governing patent infringement. ${ }^{56}$ The Court held that the statute failed to meet Boerne's congruence and proportionality test because "Congress identified no pattern of patent infringement by the States, let alone a pattern of constitutional violations." 57

In Kimel v. Florida Board of Regents, the Court held that Congress could not use its Section Five power to subject states to lawsuits for damages under the Age Discrimination in Employment Act (ADEA). ${ }^{58}$ Like Florida Prepaid, the Court in Kimel held that states could not be subject to federal age discrimination suits because of a lack of congruence and proportionality between the substantive requirements of the $\mathrm{ADEA}$ and the unconstitutional conduct that could conceivably be targeted by the Act. ${ }^{59}$

In Garrett, the Court confronted the same issue as applied to Title I of the Americans with Disabilities Act (ADA), which, among other things, prevents discrimination in employment against the disabled. ${ }^{60}$ As in Kimel, the Court in Garrett held that Congress failed to identify a pattern of irrational state discrimination in employment to justify the law's application to the states. ${ }^{61}$ Garrett, however, is most notable for the close examination the Court gave to whether Congress marshaled enough evidence of intentional state discrimination against the disabled in employment to justify allowing a remedy of monetary damages against the states.

The Court began by stating that the inquiry should not extend beyond the states themselves to units of local government such as cities and counties. "It would make no sense to consider constitutional violations on their part, as well as by the States themselves, when only the States are the beneficiaries of the Eleventh Amendment." 62 The Court then rejected as insufficient "half a dozen examples from the record [of employment discrimination against the disabled] that did involve States." 63 The Court stated that it was unclear whether the examples showed unconstitutional discrimination against the disabled. "But even if it were to be determined that each incident upon fuller examination showed unconstitutional action on the part of the State, these incidents taken together fall

56 Florida Prepaid Postsecondary Educ. Expense Bd. v. Coll. Sav. Bank, 527 U.S. 627, 647 (1999).

57 Id. at 640 .

${ }^{58}$ Kimel v. Florida Bd. of Regents, 528 U.S. 62, 67 (2000).

${ }^{59} \mathrm{Id}$. at 83.

${ }^{60}$ Bd. of Trs. v. Garrett, 531 U.S. 356, 360-61 (2001).

61 See Kimel, 528 U.S. at 89; Garrett, 531 U.S. at 368.

62 Garrett, 531 U.S. at 369.

${ }^{63} \mathrm{Id}$. 
far short of even suggesting the pattern of unconstitutional discrimination on which $\S 5$ legislation must be based." 64

Finally, the Court rejected "unexamined, anecdotal accounts" of discrimination by the states submitted to a congressional task force considering discrimination against the disabled. ${ }^{65}$ The accounts were not submitted directly to Congress, and the legislative findings supporting passage of the ADA contained nothing indicating a pattern of employment discrimination by the states. ${ }^{66}$

The Court concluded by comparing the evidentiary record before it in Garrett with the record in South Carolina v. Katzenbach:

The ADA's constitutional shortcomings are apparent when the Act is compared to Congress's efforts in the Voting Rights Act of 1965 to respond to a serious pattern of constitutional violations. In South Carolina v. Katzenbach, we considered whether the Voting Rights Act was "appropriate" legislation to enforce the Fifteenth Amendment's protection against racial discrimination in voting. Concluding that it was a valid exercise of Congress' enforcement power under $\S 2$ of the Fifteenth Amendment, we noted that "[b]efore enacting the measure, Congress explored with great care the problem of racial discrimination in voting."

In that Act, Congress documented a marked pattern of unconstitutional action by the States. State officials, Congress found, routinely applied voting tests in order to exclude African-American citizens from registering to vote. Congress also determined that litigation had proved ineffective and that there persisted an otherwise inexplicable 50-percentage-point gap in the registration of white and African-American voters in some States. Congress' response was to promulgate in the Voting Rights Act a detailed but limited remedial scheme designed to guarantee meaningful enforcement of the Fifteenth Amendment in those areas of the Nation where abundant evidence of States' systematic denial of those rights was identified. ${ }^{67}$

Four Justices dissented in Garrett. The dissent detailed what it characterized as "powerful evidence" of discriminatory treatment against the disabled in employment that justified the law's application to the states. ${ }^{68}$ Furthermore, the dissent derided the majority for treating Congress as an "administrative agency" whose record it was reviewing, arguing that:

64 Id. at 370 .

65 Id.

${ }^{66}$ Id. at $370-71$. The Court concluded that "[e]ven if it were possible to squeeze out of these examples a pattern of unconstitutional discrimination by the States, the rights and remedies created by the ADA against the States would raise the same sort of concerns as to congruence and proportionality as were found in City of Boerne." Id. at 372.

${ }^{67} \mathrm{Bd}$. of Trs. v. Garrett, 531 U.S. 356, 373 (2001) (citations and footnote omitted).

68 Id. at 378. 
There is simply no reason to require Congress, seeking to determine facts relevant to the exercise of its $\S 5$ authority, to adopt rules or presumptions that reflect a court's institutional limitations.... Unlike courts, Congress directly reflects public attitudes and beliefs, enabling Congress better to understand where, and to what extent, refusals to accommodate a disability amount to behavior that is callous or unreasonable to the point of lacking constitutional justification. $^{69}$

As Post and Siegel remark, Garrett's "implicit assumption that Congress can exercise its Section 5 power only on the basis of the same kind of concrete and specific evidence of illegal conduct that a court is required to assemble in reaching a judgment about the liability of parties."70

The Garrett evidentiary standard is indeed a tough one to meet, and I now turn to consider whether Congress could meet that standard if it renews Section Five of the Voting Rights Act. After that consideration, I return to the Court's jurisprudence, examining the extent to which Garrett's evidentiary standard survives intact under the Court's two most recent congressional power cases, Hibbs and Lane, and how these cases (along with an important recent case construing the current preclearance provision of the Act) affect the question of congressional power to renew Section Five. ${ }^{71}$

\section{BULL CONNOR IS DEAD: FINDING EVIDENCE OF A CONTINUING NEED FOR PRECLEARANCE AFTER NEARLY ForTy YEARS OF SECTION FIVE}

\section{A. The Bull Connor is Dead Problem}

The Bull Connor is Dead problem is simply that because Section Five of the Voting Rights Act has been in effect in many places for nearly four decades, states do not engage in much activity that demonstrates purposeful racial discrimination. The very fact that Section Five has served as a good deterrent to such behavior complicates the task of renewal. How then can Congress point to sufficient intentionally discriminatory acts by the states to justify the strong remedy of having every voting change in a covered jurisdiction subject to federal preclearance?

If Congress cannot point to actual incidents of discrimination, it might examine instead the hypothetical question whether covered jurisdictions would engage in intentionally discriminatory voting practices and procedures if Section Five were not renewed. In so doing, Congress may be tempted to hearken back to the history of voting rights abuses chronicled in detail in earlier congressional

69 Id. at 384.

${ }^{70}$ Robert C. Post \& Reva B. Siegel, Protecting the Constitution from the People: Juricentric Restrictions on Section Five Power, 78 IND. L.J. 1, 14 (2003).

71 See discussion infra Part IV. 
hearings on the enactment of the Act in 1965 and its subsequent renewals. Those hearings revealed a strong history and pattern of state abuse. As chronicled by Bybee, following Reconstruction and continuing up to enactment of Section Five, southern states used a variety of methods intended to limit the voting power of African-Americans:

Among the most important forms of structural discrimination were registration barriers (such as the poll tax, grandfather clauses, and literacy tests); white primaries (to reduce blacks to the role of ratifying white-approved candidates); gerrymandering (to concentrate blacks into few districts); annexation (to alter the composition of the electorate); at-large voting (to submerge minority populations); and the redesign of governing bodies (to reduce, for example, the. total number of elected offices). ${ }^{72}$

But these violations occurred at least decades ago. Bull Connor, the notorious Commissioner of Public Safety in Birmingham, Alabama, who once turned attack dogs on civil rights marchers, died in $1973 . .^{73}$ Most state legislators active in the pre-1965 days are no longer in the legislature, ${ }^{74}$ and those who remain have taken much more conciliatory public positions on questions of race. The recentlydeceased Strom Thurmond comes to mind as an example of a southern politician whose public positions on race changed significantly over the years.

How can Congress prove that there would be a significant problem with covered states if Section Five is not renewed? Can Congress show, in the words of Garrett, that the sunset of preclearance would lead again to "States' systematic denial of" the voting rights of African-Americans or others, or to states that "routinely appl[y] voting tests in order to exclude African-American citizens from registering to vote," or something equivalently egregious to justify the preclearance remedy ${ }^{75}$ The evidentiary burden will be especially difficult to meet if Congress passes a permanent preclearance requirement, as opposed to a temporally limited one. ${ }^{76}$

Assuming Congress cannot dredge up enough recent examples of intentional discrimination in voting by the states that would be covered by Section Five to

72 Keith J. Bybee, Mistaken IdentTtY: The Supreme Court and the Polmtics of MINORITY REPRESENTATION 15 (1998).

73 Wes Boruki, Connor, Theophilius Eugene "Bull," in 1 CIVIL RIGHTS NN THE UNITED STATES 190 (Waldo E. Martin \& Patricia Sullivan eds., 2000).

${ }^{74} \mathrm{Cf}$. Victor Andres Rodriguez, Comment, Section 5 of the Voting Rights Act of 1965 After Boeme: The Beginning of the End of Preclearance?, 91 CAL. L. REV. 769, 803 (2003) ("[O]fficials with a history of abusing people's voting rights are not likely to police themselves.").

${ }^{75}$ Bd. of Trs. v. Garrett, 531 U.S. 356, 373 (2001).

${ }^{76}$ Cf. City of Boerne v. Flores, 521 U.S. 507, 533 (1997) (noting that geographic and temporal limitations "tend to ensure Congress' means are proportionate to ends legitimate under § 5"). 
justify the preclearance procedures, it might turn to proxies to prove that such discrimination would emerge in the absence of preclearance renewal. I consider the two proxy approaches suggested by other commentators, and explain why I do not believe either approach is likely to have much success under the Garrett standard.

\section{B. The Problem with Proxies}

\section{The Limited Relevance of Department of Justice Preclearance Statistics}

Rodriguez suggests that DOJ statistics on preclearance provide evidence that Section Five renewal would be congruent and proportional to proven state violations. He points both to the high number of preclearance requests and to the absolute number of objections to preclearance interposed by the DOJ as a proxy for proof of intentional discrimination..$^{77}$ On the high number of preclearance requests, Rodriguez argues that "there continue to be multiple opportunities for mischief on the part of election officials and legislatures." 78 On the absolute number of objections, he notes that since 1982, "the DOJ has continued to enter a significant number of objections." 79

These statistics appear to be poor proxies for intentionally discriminatory state action in voting, for a number of reasons. First, the absolute number of preclearance requests demonstrates nothing more than that states and local jurisdictions covered by Section Five have been endeavoring to make a large number of changes in voting practices and procedures and submitting those changes to DOJ for approval. Figure 1, compiled from statistics I obtained from DOJ through a Freedom of Information Act request, ${ }^{80}$ indeed confirms that the number of preclearance requests has generally been rising, though it has been decreasing in the last decade. But the number tells us nothing about how much mischief the states would or would not do in the absence of Section Five. A potential for mischief is not the same as mischief itself.

${ }^{77}$ Rodriguez, supra note 74, at 804.

78 Id.

${ }^{79}$ Id. at 807 . Rodriguez also believes the fact that Republicans headed the DOJ and set forth objections "further indicates the serious nature of the violations." Id. He offers no evidence, however, to support the assertion.

80 Department of Justice, Civil Rights Division, Complete Listing of Objections Pursuant to Sections 3(c) and 5 of the Voting Rights Act of 1965, June 30, 2003 (on file with the author). 
Figure 1: Preclearance Submissions Over Time

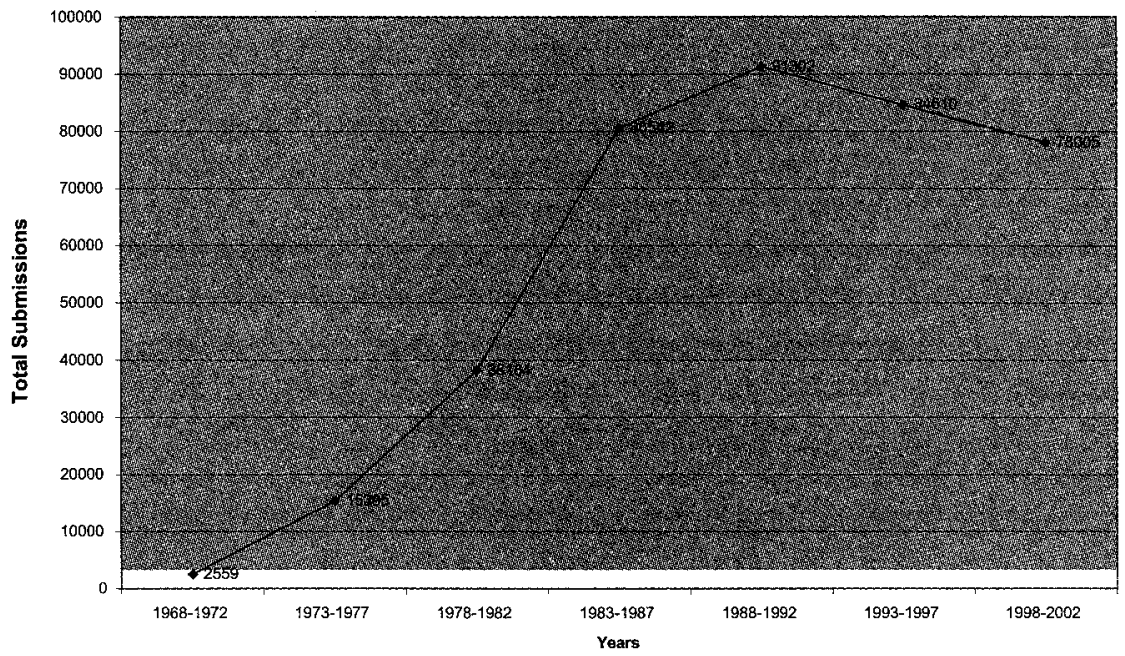

Rodriguez also overstates the significance of the number of objections interposed by DOJ. Rodriguez presents data on the number of objections over time, similar to the data in Figure 2:

Figure 2: DOJ Objections Over Time

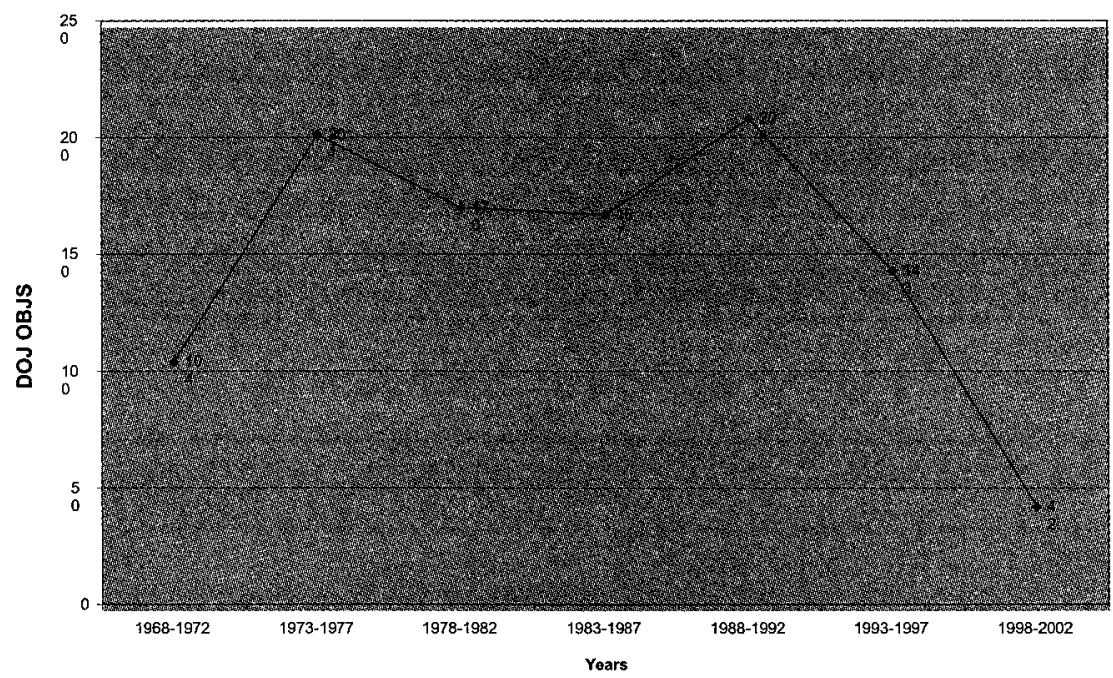

Whether or not these represent a large number in the abstract, Rodriguez errs in failing to control for the increase in the number of submissions. All else being equal, the number of objections should rise with the number of submissions, assuming a constant rate of objectionable conduct. 
Figure 3 looks at objections as a percentage of preclearance submissions over time. The graph tells a very interesting story. Objection rates exceeded $4 \%$ of total submissions in the first five years of the Voting Rights Act. They fell precipitously to $1.31 \%$ in the next five-year period and have been falling steadily ever since, down to $0.05 \%$ from $0.23 \%$ in the last three five-year periods.

Figure 3: Objections as a Percentage of Preclearance Submissions Over Time

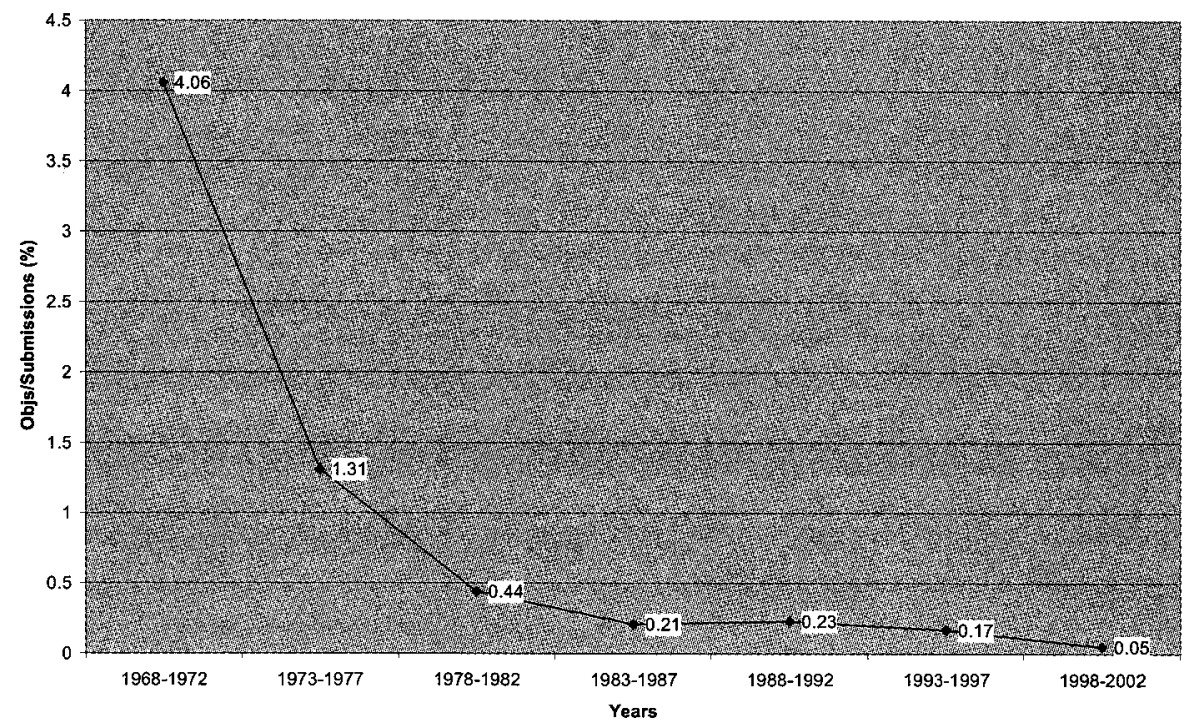

These figures, showing a trivial number of objections, do not prove an absence of discriminatory intent on the part of state officials. Perhaps Section Five is working well as a deterrent, and there is little reason to submit discriminatory voting changes that the DOJ will reject. And these figures do not include compromises between the DOJ and states whereby states made changes to avoid DOJ interposing an objection. So there may be more objectionable conduct out there not captured by these statistics.

But there is good reason to believe that these figures overstate the extent of the problems of discrimination. A number of DOJ objections over the years have been based on the DOJ's aggressive theories about how Section Five should be enforced. For example, the DOJ took the position that it would not grant preclearance to a state's redistricting plan unless the plan contained the maximum number of majority-minority districts that it was possible for a jurisdiction to create. And the DOJ took the position that it would not grant preclearance under Section Five of a plan it believed violated Section Two of the Voting Rights Act. 
The Supreme Court, however, rejected these positions, ${ }^{81}$ and we should remove from the calculations those DOJ objections based upon interpretation of Section Five going beyond eliminating retrogressive intent or effects. Although precise figures are not available, Rodriguez notes that four objections in 2002 concerned redistricting cases in which the jurisdiction lowered the percentage of minority voters in districts to a smaller percentage than had existed in the past plan..$^{82}$ Since those objections, the Supreme Court has made it clear that such plans should be precleared, so long as the state can prove that there is sufficient cross-over voting by white voters and other factors so that the position of minorities has not been made worse off under a loose, totality of the circumstances approach. ${ }^{83}$ Thus, the DOJ figures overly inflate the extent to which states have attempted to make retrogressive changes, at least as retrogression is now understood by the Court.

In sum, I see very little in the DOJ evidence that Congress could use to support a case for a renewed Section Five.

\section{The Limited Value of Evidence of Private Racist Voting Choices in Proving State Discrimination}

Both Karlan and Winke point to evidence of private racist voting choices as a means of proving the case for the constitutionality of a renewed Section Five. Historically, white voters did not vote for minority candidates, though the rate of such racially polarized voting has been declining over time, particularly beginning in the 1990s. ${ }^{84}$

Karlan, writing after Boerne but before the other New Federalism cases, considered the extent to which evidence of racially polarized voting could support Section Five. Although acknowledging that white voters' choices "were constitutionally protected even if they were based on outright racism," Karlan contends that "the state was operating a forum that enabled white voters to engage in racial discrimination." $" 85$

Building on Karlan, Winke tries to tie the private voting decisions of individuals to state-directed redistricting:

81 See Reno v. Bossier Parish Sch. Bd., 528 U.S. 320, 341 (2000); Reno v. Bossier Parish Sch. Bd., 520 U.S. 471, 474 (1997); Miller v. Johnson, 515 U.S. 900, 928 (1995).

82 Rodriguez, supra note 74, at 812 n. 242.

83 Georgia v. Ashcrof, 539 U.S. 461 (2003). See infra Part III.B.

84 Richard H. Pildes, Is Voting-Rights Law Now at War with Itself?, 80 N.C. L. REV. 1517, 1523-29 (2002).

85 Pamela S. Karlan, Two Section Twos and Two Section Fives: Voting Rights and Remedies After Flores, 39 WM. \& MARY L. REV. 725, 737-38 (1998). 
Where government actors can rely on a racially divided electorate in structuring the electoral process, discrimination can take subtle and facially neutral forms. Redistricting, for example, can work to minimize the political participation of minorities when those drawing boundary lines take cognizance of the willingness of their constituents to support minority candidates. ${ }^{86}$

He concludes that given the combination of private and government action, the courts could decide that "the opportunity for minority participation was sufficiently restricted to create an inference that intentional racial discrimination was at work."87

No doubt these are creative arguments intended to substitute the available evidence of racially polarized voting for the missing direct evidence of intentional state discrimination that Congress highlighted as late as $1982 .{ }^{88}$ However, it is hard to see how this evidence is enough to satisfy the requirements of Boerne and Garrett. These cases focus on unconstitutional action by the states. Whether or not redistricting "can work to minimize the political participation of minorities, the courts will need some proof of intentionally discriminatory conduct by the states. Winke posits a plausible relationship, but fails to point to any proof that states subject to preclearance engage in intentionally discriminatory conduct.

Even accepting Winke's argument, preclearance may exceed "reasonably prophylactic legislation"90 unless a new coverage formula requires preclearance only in jurisdictions with continued racially polarized voting and perhaps a history of using that polarization in the districting process so as to minimize the success of minority candidates. Even in those jurisdictions, a permanent preclearance requirement seems doomed to fail as a remedy that is neither congruent nor proportional.

\section{A Caveat}

Justice Black, dissenting in the 1966 Katzenbach case, described the extent of the intrusion into state sovereignty that Section Five worked as:

the inevitable effect of any such law which forces any one of the States to entreat federal authorities in far-away places for approval of local laws before they can

${ }^{86}$ Paul Winke, Why the Preclearance and Bailout Provisions of the Voting Rights Act Are Still a Constitutionally Proportional Remedy, 28 N.Y.U. REV. L. \& SOC. CHANGE 69, 104 (2003).

87 Id. at 105.

${ }^{88}$ On the 1982 evidence, see Karlan, supra note 85, at 734-36; Laughlin McDonald, The 1982 Extension of Section 5 of the Voting Rights Act of 1965: The Continued Need for Preclearance, 51 TENN. L. REV. 1 (1983).

${ }^{89}$ Winke, supra note 86 , at 104.

${ }^{90}$ Kimel v. Florida Bd. of Regents, 528 U.S. 62, 88 (2000). 
become effective is to create the impression that the State or States treated in this way are little more than conquered provinces. ${ }^{91}$

Justice Black's words, which did not convince the Court in 1966-a Court that was confronted with massive and uncontradicted evidence of intentional state discrimination in voting practices-may get a more receptive hearing after 2007. Predicting the Court's reaction to this evidence, however, has been made more difficult by the most recent developments in the Court's jurisprudence in this area, to which I turn in the next Part.

But even putting Hibbs and Lane aside, it is not clear that the Court would have the stomach to overturn a renewed preclearance provision. The early voting rights cases are considered by many to be a high-water mark for the Court in fostering racial equality in this country. As we have seen, in the Boerne-line of cases the Court has pointed repeatedly to Katzenbach and the early cases as an appropriate use of congressional power. ${ }^{92}$ The Court may be reluctant to undermine those precedents in evaluating the new Section Five, even though the evidentiary issue will be somewhat different under a renewed Section Five.

It also might be politically unpopular for the Court to overturn a renewed Section Five. Rodriguez remarked that:

[a]llowing Section 5 to lapse would be a significant blow to minority communities because it would signal to many in those communities that Congress was no longer determined to be vigilant in its protection of minorities' right to vote and no longer interested in pursuing a vigorous campaign against voting rights abuses. ${ }^{93}$

We have already seen a casual application of the Boerne standard in the 1999 case Lopez v. Monterey County. ${ }^{94}$ In Lopez, a group of Latino voters from a county in California covered under the 1982 Voting Rights Act's preclearance requirement challenged the state's failure to preclear changes in its laws governing judicial elections in that county. ${ }^{95}$

The Court rejected California's argument that it would exceed congressional enforcement power under the Fifteenth Amendment to require the State to preclear its voting changes in the absence of evidence that the state had been one of the "historical wrongdoers in the voting rights sphere." ${ }^{.96}$ Although the Court cited Boerne, it stated that its prior voting rights precedents of Katzenbach and

\footnotetext{
91 South Carolina v. Katzenbach, 383 U.S. 301, 359-60 (1966).

92 See discussion supra note 68.

93 Rodriguez, supra note 74 , at 811.

94525 U.S. 266 (1999).

$95 \mathrm{Id}$. at 274.

${ }^{96} I d$. at 282.
} 
City of Rome, both of which had upheld preclearance provisions, governed the case. ${ }^{97}$ Noting that the Act "by its nature, intrudes on state sovereignty," the Court upheld the intrusion because it "burden[ed] state law only to the extent that [the] law affects voting in jurisdictions properly designated for coverage."98 Justice Thomas dissented in Lopez, intimating that Congress did not have the authority to require preclearance by California. ${ }^{99}$

We should not make too much of Lopez, however. Although Lopez was decided after Boerne, it pre-dated Garrett and its focus on the evidentiary questions. In addition, Lopez concerned the constitutionality of the 1982 renewal of the preclearance provisions. The case thus does not control how the Court would address a challenge to the constitutionality of a renewed Section Five in 2007.

\section{THE NEWER NEW FEDERALISM: HOPE FOR A RENEWED SECTION FIVE?}

\section{A. The Relevance of Hibbs and Lane}

In Nevada Department of Human Resources v. Hibbs ${ }^{100}$ and Tennessee v. Lane ${ }^{101}$ the Court backpedaled somewhat from the strict evidentiary burden it set forth in Garrett. Some of the particular twists and turns the Court has added to the Boerne/Garrett inquiry in these cases are good news for supporters of a renewed preclearance provision.

Hibbs involved a challenge to the Family and Medical Leave Act of 1993 (FMLA). ${ }^{102}$ Nevada discharged a state employee after he failed to return to work because he was caring for his ailing spouse. ${ }^{103}$ The employee sued the state for damages, arguing that its conduct violated the FMLA, which, among other things, gives an employee a right to take a leave of up to twelve weeks to care for a spouse with a serious health condition. ${ }^{104}$

The State argued that Congress exceeded its authority by allowing citizens to sue states for damages under the FMLA because there was not enough evidence of state discrimination on the basis of gender to justify imposing the mandatory leave policy on the states. ${ }^{105}$ The Court disagreed, holding that the evidence of

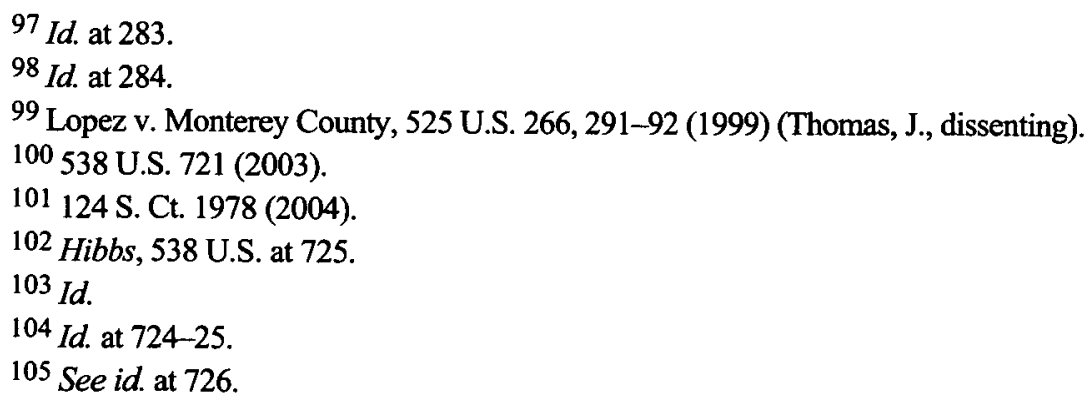


gender-based discrimination by the states was sufficient. ${ }^{106}$ The opinion is curious, for reasons Amar details ${ }^{107}$ and I do not repeat here; there was no more evidence of state discrimination in Hibbs than in Garrett.

One of the explanations the Court gave in Hibbs for distinguishing Garrett is potentially important in assessing the preclearance question. The Court noted that a higher level of scrutiny applies in assessing the constitutionality of legislation that discriminates on the basis of gender (at issue in Hibbs) compared to the rational basis level of scrutiny that applies in assessing the constitutionality of legislation that discriminates on the basis of age (at issue in Garrett) or disability (at issue in Kimel). ${ }^{108}$ The Court held that given this distinction, "it was easier for Congress to show a pattern of state constitutional violations" in Hibbs. ${ }^{109}$

Amar explained that this analysis:

cheats a bit as to the key issue. The central queries under the "congruence and proportionality" test are these: How often are States violating the Fourteenth Amendment, and how tailored is the Congressional fix to these violations? To say that gender classifications are subject to a more stringent standard of review than are disability classifications doesn't really tell us how often States are violating the constitutional rights of women versus the constitutional rights of the disabled. ${ }^{110}$

Amar is right that the level of scrutiny should be irrelevant to the congruence and proportionality analysis. Nonetheless, the fact that the Court has said otherwise suggests that the Court may consider it relatively easier for Congress to show a pattern of racial discrimination supporting a renewed preclearance provision: Race discrimination is subject to strict scrutiny, stricter scrutiny than gender claims. ${ }^{111}$

Lane's treatment of the evidence is in some ways more important than Hibbs for the preclearance question. The case concerned Title II of the ADA, and in particular the question whether a state could be subject to a suit for damages for failing to make its courthouses reasonably accessible to the disabled. ${ }^{112}$ One of the

${ }^{106}$ Id. at 730-75 (recounting evidence). But see id. at 745-56 (Kennedy, J., dissenting) (arguing that the evidence Congress put forward of intentional discrimination by the states was insufficient).

107 Vikram David Amar, The New "New Federalism," 6 GREEN BAG 2D 349, 350-54 (2003).

108 Nevada Dept. of Human Res. v. Hibbs, 538 U.S. 721, 735-36 (2003).

109 Id. at 736.

110 Amar, supra note 107, at 353.

111 The Hibbs Court also emphasized a point it had made in earlier cases: "Congress may enact so-called prophylactic legislation that proscribes facially constitutional conduct, in order to prevent and deter unconstitutional conduct." Hibbs, 538 U.S. at 727-28.

112 Tennessee v. Lane, 124 S. Ct. 1978, 1982 (2004). 
Lane plaintiffs was a paraplegic who alleged he could not use a wheelchair to access a courthouse for a criminal hearing. ${ }^{113}$ The other plaintiff was a court reporter with disabilities who alleged that because of her disability, she could not gain access to a number of county courthouses and, as a result, lost her ability "to participate in the judicial process." 114 The Court held that Congress had the power to make states liable for damages for failing to provide access to the courts under Title II of the ADA. ${ }^{115}$

Some of what is significant in Lane about the Boerne inquiry has little bearing on the preclearance question. ${ }^{116}$ For our purposes, I focus primarily on the evidentiary question. The Court began its evidentiary analysis of the extent to which states engage in unconstitutional discrimination against the disabled in providing access to the courts with a general discussion of the pre-ADA "backdrop of pervasive unequal treatment in the administration of state services and programs, including systematic deprivations of fundamental rights" for the disabled. ${ }^{117}$ The Court pointed to discrimination against the disabled in voting, marrying, and serving as jurors, and cited to court cases identifying

113 He refused to crawl up or be carried up two flights of stairs to get into the courtroom. Id. at $1982-83$.

114 Id. at 1983.

115 Id. at 1994.

116 For example, the Court in Lane explained that when faced with a broad statute applicable in a variety of contexts - as opposed to the preclearance statute, applicable to the single context of a covered jurisdiction making a change in a voting practice or procedure - the courts in conducting the Boerne inquiry must focus on the application of the statute to a specific context. See id. at 1988-89, 1993. Thus, rather than asking whether Title II of the ADA as a whole could be applied to state governments as a congruent and proportional remedy to intentional state discrimination against the disabled, the majority considered its application only to courthouses. See id. at 1990 n. 14

The answer to the question Boerne asks - whether a piece of legislation attempts substantively to redefine a constitutional guarantee-logically focuses on the manner in which the legislation operates to enforce that particular guarantee. It is unclear what, if anything, examining Title II's application to hockey rinks or voting booths can tell us about whether Title II substantively redefines access to the courts.

Id. at 1993.

The Chief Justice expressed "grave doubts" as to whether the majority correctly applied what he characterized as an "as applied" approach to congressional power.

Title II is not susceptible of being carved up in this manner, it applies indiscriminately to all "services," "programs," or "activities" of any "public entity." Thus, the majority's approach is not really an assessment of whether Title II is "appropriate legislation" at all, but a test of whether the Court can conceive of a hypothetical statute narrowly tailored enough to constitute valid prophylactic legislation.

Id. at 2005 (Rehnquist, C.J., dissenting) (citation omitted).

117 Tennessee v. Lane, 124 S. Ct. 1978, 1989 (2004). 
"unconstitutional treatment of disabled persons by state agencies in a variety of settings, including unjustified commitment, the abuse and neglect of persons committed to state mental health hospitals, and irrational discrimination in zoning decisions." 118

The Court then turned to the evidence Congress considered before passing the ADA. It pointed in particular to a 1983 report before Congress showing that seventy-six percent of public services and programs housed in state-owned buildings were inaccessible and unusable by persons with disabilities; 1988 testimony to a House of Representatives subcommittee from two persons with disabilities "who described the physical inaccessibility of local courthouses;" and "numerous examples" in a 1990 task force report "of the exclusion of persons with disabilities from state judicial services and programs."119

The Court noted that in assessing the evidence, it was appropriate to examine not only violations by the state, but also constitutional violations on the part of nonstate governmental actors, such as city and county officials. ${ }^{120}$ This determination seemed directly contrary to Garrett. ${ }^{121}$

The majority's opinion thus appeared to significantly lower the evidentiary burden for Congress, a fact the majority did not expressly acknowledge. The result is not so surprising considering the Justices making up the Lane majority: the four most liberal members of the Court, who had dissented in Garrett, along with perennial swing voter, Justice O'Connor. That same set of Justices, along with Chief Justice Rehnquist, joined in the other permissive Boerne opinion, Hibbs.

Chief Justice Rehnquist, who wrote the Hibbs majority opinion but dissented in Lane, rejected the Lane majority's conclusion that the Congress had identified a pattern of violations by states against the disabled to justify Title II's damage remedy, at least as applied to courthouse access. ${ }^{122}$ First, the Chief Justice characterized the "backdrop" of discrimination against the disabled invoked by the majority as "outdated, generalized evidence." 123 Second, he noted that the "bulk of the Court's evidence concerns discrimination by nonstate governments, rather than the States themselves," evidence the Chief Justice dismissed as "irrelevant."124 Finally, the Chief Justice characterized the congressional task force evidence cited by the majority as the same "unexamined anecdotal" evidence of discrimination against the disabled rejected in Garrett. "Most of the brief anecdotes do not involve States at all, and those that do are not sufficiently

118 Id. (citations omitted).

119 Id. at 1991.

${ }^{120} \mathrm{Id}$. at $1991 \mathrm{n} .16$.

121 See Bd. of Trs. v. Garrett, 531 U.S. 356, 369 (2001).

122 Lane, 124 S. Ct. at 1999-2002 (Rehnquist, C.J., dissenting).

${ }^{123}$ Id. at 1999 (Rehnquist, C.J., dissenting).

${ }^{124}$ Id. (Rehnquist, C.J., dissenting). 
detailed to determine whether the instances of 'unequal treatment' were irrational, and thus unconstitutional ...."125

The Chief Justice concluded that "there is nothing in the legislative record or statutory findings to indicate that disabled persons were systematically denied the right to be present at criminal trials, denied the meaningful opportunity to be heard in civil cases, unconstitutionally excluded from jury service, or denied the right to attend criminal trials." 126

The Lane evidentiary analysis may ease the burden for supporters of renewed preclearance in three significant ways. First, the analysis would obscure the Bull Connor is Dead problem by allowing the use of old (what the Chief Justice referred to as "outdated") evidence to support the new law. Lane was a 2004 decision, yet most of the evidence before Congress to which the Court cited was gathered in the 1980s and published in the 1990s. ${ }^{127}$

If there was enough evidence before Congress to support the 1982 preclearance decision (a point confirmed under the Boerne standard by Lopez $v$. Monterey County ${ }^{128}$ ), then perhaps that same evidence can be relied upon to support renewed preclearance in 2007 , at least for a preclearance provision that is similarly limited in temporal scope to the twenty-five-year term of the 1982 preclearance renewal.

Second, Congress may rely upon general evidence of racially discriminatory conduct in voting by state, county, and city officials in covered jurisdictions to support renewed preclearance. It need not point only to the actions of state officials, ${ }^{129}$ and apparently it need not provide too much particularity to show that each jurisdiction which would be covered by a renewed preclearance provision had an identically egregious recent history of racial discrimination in voting.

One caveat on this second point: to satisfy Justice Scalia, who wrote separately in Lane, it will be necessary to point to actions of officials in each state that would be subject to preclearance. ${ }^{130}$ In Lane, Justice Scalia announced that for reasons of stare decisis, he would now hold that Congress has broad latitude

125 Id. at 2000 (Rehnquist, C.J., dissenting) (citations omitted).

${ }^{126}$ Id. (Rehnquist, C.J., dissenting); see also id. at 2000-05 (Rehnquist, C.J., dissenting) (criticizing further the sufficiency of the majority's evidence).

127 See Tennessee v. Lane, 124 S. Ct. 1978, 1990 (2004).

128525 U.S. 266 (1999).

${ }^{129}$ In Lane, the Court looked at ADA violations by local courthouses because those courts are treated as arms of the state for Eleventh Amendment purposes. Lane, $124 \mathrm{~S}$. Ct. at 1991, n.16. In a challenge to a renewed preclearance provision, the question would not be Eleventh Amendment immunity but Congress's substantive authority to renew preclearance under the Fourteenth or Fifteenth Amendments. When the discussion relates to Congress's enforcement powers generally, it makes no sense to ignore a record of constitutional violations by localities. Thanks to Sam Bagenstos for raising this point.

${ }^{130}$ Id. at 2012 (Scalia, J., dissenting). 
to pass legislation aimed at combating racial discrimination. ${ }^{131}$ But he has insisted that Congress may impose laws aimed at eradicating racial discrimination "only upon those particular States in which there has been an identified history of relevant constitutional violations."132 Thus, to meet Justice Scalia's standard, more specific state-by-state evidence of intentional racial discrimination in voting may be required.

Third, the Court may look to court decisions demonstrating state (and local) racial discrimination in voting, as well as reports submitted to Congress, documenting at least a handful of intentional state violations of the voting rights of members of protected minority groups. Supporters of a renewed preclearance would be well-advised to begin preparing those reports now, and fill the record with as much anecdotal (and more systematic, if available) evidence of intentional state racial discrimination in voting to support a renewed preclearance provision.

Another aspect of Lane also increases the prospects for the Court to uphold a renewed preclearance provision. Lane explained that in cases such as those under the ADA involving only rational basis scrutiny, Congress may nonetheless impose a "strong" remedy when the statute protects "fundamental rights." 133 The Lane Court noted that Title II of the ADA:

like Title I, seeks to enforce [a] prohibition on irrational disability discrimination. But it also seeks to enforce a variety of other basic constitutional guarantees, infringements of which are subject to more searching judicial review. These rights include some, like the right of access to the courts at issue in this case, that are protected by the Due Process Clause of the Fourteenth Amendment. ... While $\S 5$ authorizes Congress to enact reasonably prophylactic remedial legislation, the appropriateness of the remedy depends on the gravity of the harm it seeks to prevent. "Difficult and intractable problems often require powerful remedies," but it is also true that "[s]trong measures appropriate to address one harm may be an unwarranted response to another, lesser one."134

A renewed preclearance provision involves race discrimination, so strict scrutiny already applies. But it also involves the right to vote, itself a fundamental right. The tone of the Court's opinion in Lane on the fundamental rights question suggests that the Court is willing to defer more to Congress to remedy the more

${ }^{131}$ Id. at 2012-13 (Scalia, J., dissenting). Outside the context of racial discrimination, Justice Scalia has now rejected Boerne's congruence and proportionality test in favor of a more narrow reading of what it means to "enforce" the Fourteenth Amendment. See id. Justice Scalia's position that racial discrimination might be different is somewhat analogous to arguments put forward in Ellen D. Katz, Federalism, Preclearance, and the Rehnquist Court, 46 VILL. L. REV. 1179 (2001) and Pamela S. Karlan \& Daryl J. Levinson, Why Voting is Different, 84 CAL. L. REV. 1201 (1996).

132 Lane, 124 S. Ct. at 2012 (Scalia, J., dissenting).

133 Id. at 1989.

134 Id. at 1988-89 (citations omitted). 
that Congress seeks to protect fundamental rights. Such a conclusion can only bode well for a renewed preclearance provision challenged as an improper exercise of congressional power.

-Although the changes in Hibbs and Lane certainly increase the chances that a renewed preclearance provision would satisfy Boerne, the case is not a slam dink. Congress will still be required to come forward with some evidence of intentional discriminatory conduct in voting. The Court did not give Congress a pass on producing evidence; it merely lowered, at least for now, the extent of the evidentiary burden.

More importantly, with potential changes in Court personnel between now and the time that Congress would pass a renewed preclearance provision to be challenged in the courts, the stricter evidentiary standard of Garrett could be revived by a new Court majority. A Congress that wants renewed preclearance sustained has every incentive to be as comprehensive as possible in chronicling problems of purposeful racial discrimination in voting.

\section{B. How Changes in the Preclearance Standard May Help a Renewed Preclearance Provision Pass the Boerne Test}

Recent developments in the statutory law governing preclearance also increase the chances that a renewed preclearance provision would be held constitutional. By making it easier for covered jurisdictions to obtain preclearance, these cases decrease the burden that preclearance imposes on the states and therefore make the preclearance remedy appear more congruent and proportional to the scope of state violations. ${ }^{135}$ Current law provides that to obtain

135 In a somewhat parallel context, the Second Circuit recently held that it would not construe Section Two of the Voting Rights Act to bar felon disenfranchisement laws because such a construction could well mean that Section Two violates the Boerne "congruence and proportionality" standard. Muntaqim v. Coombe, 366 F.3d 102, 130 (2d Cir. 2004), rehearing en banc granted Dec. 23, 2004. The Muntaqim Court stated:

Based on recent decisions of the United States Supreme Court, we conclude that [applying Section Two of the Voting Rights Act] would alter the constitutional balance between the States and the Federal Government if it were construed to extend to state felon disenfranchisement statutes such as [New York's felon disenfranchisement statute]. In the absence of a clear statement from Congress to support that construction of the statute, we hold that [Section Two] does not extend to [the felon disenfranchisement statute].

Id. Likewise, a dissenting Ninth Circuit judge stated:

There is yet a more fundamental problem with extending the VRA to reach felon disenfranchisement laws: Doing so seriously jeopardizes its constitutionality. "[A]ny attempt by Congress to subject felon disenfranchisement provisions to the 'results' methodology of [the VRA] would pose a serious constitutional question concerning the scope of Congress's power to enforce the Fourteenth and Fifteenth Amendments." 
preclearance, a state must demonstrate that a change in a voting practice or procedure does not have a "discriminatory purpose or effect." 136 The leading case on the meaning of this standard is Beer v. United States, in which the Supreme Court explained that discriminatory purpose or effect in the preclearance context means a purpose or effect to "retrogress," that is, to make the position of minorities worse off than they were under the old law in the covered jurisdiction. ${ }^{137}$

Since Beer, a number of significant cases have construed this so-called "nonretrogression principle." As has already been mentioned, ${ }^{138}$ in recent years the Supreme Court has repeatedly resisted efforts-mainly of the DOJ-to read the nonretrogression principle broadly, such as to require that covered jurisdictions not engage in vote dilution that could violate another provision of the Voting Rights Act.

In the most important nonretrogression case since Beer, the 2003 opinion in Georgia v. Ashcroft, 139 the Court further eased the burden on covered jurisdictions. Under Beer, the nonretrogression principle was rather mechanical, at least in the redistricting context. One counted up the number of majorityminority jurisdictions under the old and new plans, and so long as the number did not go down under the new plan, the plan was to be approved as "ameliorative" and therefore nonretrogressive. ${ }^{140}$

In Georgia v. Ashcroft, however, the Court explained that even if the number of majority-minority jurisdictions goes down, a plan submitted for preclearance can still be declared ameliorative. ${ }^{141}$ The Court reached this conclusion by announcing the following principles to guide the retrogression inquiry:

First... in examining whether the new plan is retrogressive, the inquiry must encompass the entire statewide plan as a whole....

Second, any assessment of the retrogression of a minority group's effective exercise of the electoral franchise depends on an examination of all the relevant circumstances, such as the ability of minority voters to elect their candidate of choice, the extent of the minority group's opportunity to participate in the political process, and the feasibility of creating a nonretrogressive plan....

Farrakhan v. Washington, 359 F.3d 1116, 1121 (9th Cir. 2004) (Kozinski, J., dissenting from denial of rehearing en banc) (quoting Baker v. Pataki, 85 F.3d 919, 930 (2d Cir. 1996)). This issue may yet reach the Supreme Court.

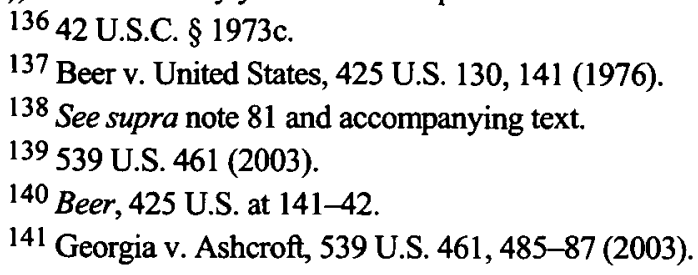


In assessing the totality of the circumstances, a court should not focus solely on the comparative ability of a minority group to elect a candidate of its choice. While this factor is an important one in the $\S 5$ retrogression inquiry, it cannot be dispositive or exclusive....

The ability of minority voters to elect a candidate of their choice is important but often complex in practice to determine. In order to maximize the electoral success of a minority group, a State may choose to create a certain number of "safe" districts, in which it is highly likely that minority voters will be able to elect the candidate of their choice. Alternatively, a State may choose to create a greater number of districts in which it is likely-although perhaps not quite as likely as under the benchmark plan-that minority voters will be able to elect candidates of their choice.

Section 5 does not dictate that a State must pick one of these methods of redistricting over another. Either option "will present the minority group with its own array of electoral risks and benefits," and presents "hard choices about what would truly 'maximize' minority electoral success." 142

As Karlan explains, "[p]ut simply, the Court [in Georgia v. Ashcroft] held that a plan could be precleared even if it reduced minority voters' ability to elect their preferred representatives, as long as it preserved their 'opportunity to participate in the political process,' an opportunity that was 'not limited to winning elections." 143

By allowing covered jurisdictions increased flexibility in defending changes in voting practices or procedures as nonretrogressive, the Court has limited the intrusion that preclearance makes on state governance. To be sure, the state still must obtain federal approval before putting into effect its own laws, and for that reason the threat of Boerne still hangs over the head of a renewed preclearance provision. But preclearance should be much easier to obtain than it was in 1965, 1982 or even 2002 , making it a less draconian remedy than it was in the past from the point of view of federalism.

\section{CAN CONGRESS FIND THE POWER TO ENACT A RENEWED PRECLEARANCE ELSEWHERE IN THE CONSTITUTION?}

Parts II and III demonstrated that, although the issue is far from settled, the Supreme Court could hold that Congress lacks the power under the Fifteenth Amendment to reenact Section Five's preclearance provisions. But could Congress act under some other power granted to it in the Constitution? One candidate is the Guarantee Clause, contained in Section Four, Article IV, of the

142 Id. at $479-80$ (citations omitted).

143 Pamela S. Karlan, Georgia v. Ashcroft and the Retrogression of Retrogression, 3 ELECTION L.J. 21, 30 (2004) (quoting Georgia v. Ashcroft, 539 U.S. 461, 482 (2003)). 
United States Constitution. ${ }^{144}$ The clause provides that "[t]he United States shall guarantee to every State in this Union, a Republican Form of Government...."145

Elsewhere I have detailed the history and potential uses of this clause. ${ }^{146}$ Beginning in Luther v. Borden, ${ }^{147}$ the Supreme Court has refused to adjudicate claims that a particular state law or practice violates the Guarantee Clause. Luther arose out of a civil war in Rhode Island in the 1840s pitting those who wanted to expand the franchise against supporters of the existing government who wished to continue use of Rhode Island's narrow suffrage requirements. ${ }^{148}$ The factions formed rival governments. The President of the United States ultimately sided with the existing government and the rebellion was quashed.

Years after the insurrection ended, the case of Luther v. Borden made it to the Supreme Court. Luther was a trespass case in which police from the existing government broke into plaintiff's home looking for evidence that he was participating in the rival electoral process. ${ }^{149}$ The plaintiff claimed trespass on grounds that the police officers had no authority to enter his home because the government for which they worked was not a "Republican" government under the Guarantee Clause. ${ }^{150}$

The Court refused to consider whether the existing Rhode Island government was "Republican" under the Guarantee Clause, declaring in the 1849 case that "[u]nder this article of the Constitution it rests with Congress to decide what government is the established one in a State."151

The Court's practice to avoid the Guarantee Clause has continued to recent times. In 1980, the Court refused to consider whether certain provisions of the Voting Rights Act violated the Guarantee Clause, holding that the "issue is not justiciable."152

If it is for "Congress to decide" what constitutes "Republican" government and to guarantee it, perhaps Congress could decide that "Republican" government

144 See Ethan J. Leib, Redeeming the Welshed Guarantee: A Scheme for Achieving Justiciability, 24 WHITTIER L. REV. 143, 218 (2002).

145 U.S. CONST. art. I, $§ 4$.

146 See Richard L. Hasen, Leaving the Empty Vessel of 'Republicanism' Unfilled: An Argument for the Continued Non-Justiciability of Guarantee Clause Cases (available at: http://ssm.com/abstract=385920) (Loyola Law School Working Paper 2003-10) (last visited Feb. 20, 2005).

14748 U.S. (7 How.) 1 (1849).

${ }^{148}$ Id. at 34-35.

149 Id. at 34 .

$150 \mathrm{Id}$. at $34-35$.

151 Id. at 42.

152 City of Rome v. United States, 446 U.S. 156, 182 n.17 (1980). But see Hasen, supra note 146 (describing other recent Supreme Court cases suggesting that at least some Guarantee Clause claims may held justiciable in the near future). 
requires preclearance. In other words, Congress could decide that to guarantee "Republican" government in those states that historically have engaged in intentional racial discrimination in voting, federal government preclearance remains warranted. Under this theory, Congress could impose preclearance to guarantee "Republican" government even absent contemporary proof of intentionally discriminatory conduct in voting.

Perhaps this end run around the New Federalism cases would be too much for the Supreme Court, causing it to start adjudicating claims under the Guarantee Clause, and in particular to determine what, precisely, "Republican" government means. Interpreting the Guarantee Clause to give Congress essentially carte blanche to make structural changes in the political process without Supreme Court oversight would work a fundamental change in Congress-Court relations, negating some of the New Federalism revolution.

For this reason, Court acquiescence in this approach is unlikely though still possible: The Court might not want to open itself up to Guarantee Clause claims, which will draw the Court even further in the political thicket. ${ }^{153}$

In any case, given the apparent difficulties the Congress would face in convincing the Court that a renewed Section Five is constitutional under its Fifteenth Amendment enforcement powers, there seems little downside for Congress also basing its passage of a renewed Section Five on the Guarantee Clause.

\section{CONCLUSION}

Congress and those individuals and organizations seeking to influence Congress will soon devote a substantial amount of time to debating the wisdom of renewing Section Five of the Voting Rights Act. Supporters (within and outside Congress) of a renewed Section Five should go into these debates with their eyes open, recognizing that the Court, rather than Congress, will have the final say on whether a renewed Section Five ultimately will have the force of law.

At the very least, these supporters need to consider making the strongest evidentiary record of intentional discriminatory conduct in voting by states to justify preclearance provisions. The evidence should target as many states as possible that would be covered by a new Section Five. If direct evidence is not available, proponents of the new law should consider whatever proxies for intentional discriminatory conduct by states might be available.

Under the existing and muddled Supreme Court precedents, it is far from clear whether Congress will be able to make the case to satisfy the Supreme Court that the "uncommon" preclearance rationale is "congruent and proportional" to prove intentional racial discrimination in voting by covered jurisdictions today. For this reason, supporters of the renewed law would do themselves a service to 
explore alternative bases for Congressional power, including congressional power under the Guarantee Clause. In the battle between Congress and the Supreme Court over the New Federalism, the preclearance provisions remain in danger of becoming the next casualty. 
